\title{
Pengembangan Sistem DAPODIKDAS pada Optimalisasi Pencarian Data Siswa Berprestasi
}

\author{
DAPODIKDAS System Development \\ in Optimizing Student Achievement Data Search
}

\author{
Dema Mathias Lumban Tobing*1, Yulianto Mustaqim², Azriel Christian Nurcahyo ${ }^{3}$, \\ Musthofa Galih Pradana ${ }^{4}$, Yusuf Hendra Pratama ${ }^{5}$ \\ 1,2,3,4,5 Magister Teknik Informatika Universitas AMIKOM Yogyakarta, \\ ${ }^{3}$ Teknik Informatika Universitas Kristen Immanuel Yogyakarta, \\ ${ }^{5}$ Teknik Informatika STMIK Bumi Gora Mataran Nusa Tenggara Barat \\ E-mail: *11namakudema@gmail.com, ${ }^{2}$ ymustaqim19@gmail.com, \\ 3azrielchristian@gmail.com, ${ }^{4}$ mgalihpradana@gmail.com, ${ }^{5}$ yusufhp92@gmail.com
}

\begin{abstract}
Abstrak
Dapodikdas serentak diterapkan pada seluruh Sekolah Dasar sejak tahun 2015, dimana banyak kemudahan yang didapatkan apabila sekolah menggunakan aplikasi tersebut seperti pemberian NISN, BOS, BSM, KIP, tunjangan dan sertifikasi guru, pendataan peserta Ujian Nasional, dan pendataan orang tua siswa. Hingga saat ini Dapodikdas belum mengakomodir kebutuhan Kemendikbud dan Sekolah dalam pencarian data siswa berprestasi. Hal ini disebabkan karena belum tersedianya fitur pencarian data siswa berprestasi sebagai bagian optimalisasi penggunaan data. Mengingat siswa berprestasi layak mendapatkan penghargaan oleh negara sesuai UU No 20 Tahun 2003 tentang Sistem Pendidikan Nasional.Pada penelitian ini dilakukan optimalisasi sistem Dapodikdas melalui penambahan fitur pencarian kepakaran data siswa berprestasi. Hasil dari penelitian ini mampu mengoptimalisasikan berupa simulasi Dapodikdas dalam pencarian siswa berprestasi. Perbandingan kecepatan akses query sedikit lebih lambat dibandingkan sistem dapodikdas saat ini namun adanya penambahan fitur pencarian kepakaran siswa mampu memenuhi kebutuhan UU No 20 Tahun 2003. Dari hasil perbandingan dilakukan uji query pencarian biodata siswa lengkap dan orang tua diperoleh Dapodikdas lebih cepat 0.00695 detik dibandingkan Dapodikdas versi optimalisasi 0.007195 detik, akan tetapi terdapat beberapa fitur kelebihan dari versi optimalisasi yaitu pencarian pembinaan siswa, seleksi siswa, dan penghargaan siswa. Penambahan fitur ini diharapkan menjadi sarana Kemendikbud dan Sekolah dalam pencarian bakat siswa berprestasi.
\end{abstract}

Kata Kunci — Dapodikdas, Kemendikbud, Optimalisasi, Kepakaran.

\begin{abstract}
Dapodikdas is simultaneously applied to all elementary schools since 2015, where many of the conveniences obtained schools use such applications as NISN, BOS, KIP, teacher's allowances and certification, National Examination, and parents. Until now, Dapodikdas not accommodate the needs of Kemendikbud and School to search of student data achievement. This is due to unavailability of data search feature of student achievement as part of data usage optimization. In this research, Dapodikdas system optimization is done through the addition of search feature of student data achievement. The result of this research is able to optimize in the form of Dapodikdas simulation in search of achievement students. The comparison of query access speed is slightly slower than the current system but the addition of search features is able to meet the needs of UU No.20 of 2003. The comparison result, it is done by query search of complete student biographical data and parents get faster 0.00695 seconds than Dapodikdas
\end{abstract}


Citec Journal, Vol. 5, No. 4, Agustus 2018 - Oktober 2018

ISSN: 2460-4259

optimization version 0.007195 second, but there are some advantages feature of optimization version that is searching student coaching, selection, and awards. The addition of this feature is expected to be a means of Kemendikbud and School in talent search for outstanding students.

Keywords — Dapodikdas, Kemendikbud, Optimalitation, Expertise.

\section{PENDAHULUAN}

Dapodik merupakan data pokok pendidikan yang diimplementasikan pada SD, SMP dan SMA dimana pada penggunaannya berbasis teknologi. Sistem Dapodik merupakan program Kemendikbud yang dibangun dengan tujuan merekam jejak semua data pendidikan mulai dari tingkat SD, SMP dan SMA. Sistem Dapodikdas adalah aplikasi penjaring data pokok pendidikan pada jenjang khusus pendidikan dasar dan menengah berdasarkan instruksi Kementerian Pendidikan dan Kebudayaan No 2 Tahun 2011[1].

Data dari Dapodikdas digunakan sebagai acuan data dalam program-program Kemendikbud pada tingkat pendidikan dasar dan menengah seperti pemberian Nomor Induk Siswa Nasional, Bantuan Operasional Sekolah, Bantuan Siswa Miskin, Kartu Indonesia Pintar, tunjangan dan sertifikasi guru, pendataan peserta Ujian Nasional, dan pendataan orang tua siswa. Apabila sekolah menolak menggunakan Dapodikdas maka beberapa fasilitas seperti di atas tidak akan diberikan oleh pihak Kemendikbud, oleh sebab itu sekolah wajib berpartisipasi aktif dalam kegiatan pendataan Dapodikdas [2].

Dapodikdas menyediakan ruang kepada pihak sekolah dalam bidang pendataan untuk melakukan pencarian siswa yang berhak mendapatkan fasilias seperti Bantuan Siswa Miskin, Kartu Indonesia Pintar (KIP), pencarian identitas siswa meliputi data orang tua, pekerjaan orang tua, penghasilan orang tua, dan pembagian rombongan belajar kelas pada siswa [3]. Dalam pendataan tersebut masih terdapat kekurangan dimana sistem ini tidak menyediakan ruang kepada pihak sekolah dalam melakukan pendataan siswa berprestasi dibidang akademik maupun nonakademik sehingga tidak adanya penjaringan yang akurat dari pihak Kemendikbud dalam memberikan penghargaan maupun pembinaan khusus kepada siswa yang berprestasi sesuai bidangnya masing-masing. Berdasarkan UU No 20 Tahun 2003 tentang Sistem Pendidikan Nasional pada BAB IV Bagian Kesatu pasal 5 ayat 4 menyebutkan bahwa: "Warga Negara yang memiliki potensi kecerdasan dan bakat istimewa berhak memperoleh pendidikan khusus”, namun belum diterapkan pada Dapodikdas.

Dari pokok permasalahan tersebut dibutuhkan pengembangan dalam sistem Dapodikdas melalui optimalisasi sistem yang ada dengan menambahkan fitur sistem pencarian kepakaran siswa. Fitur tersebut berfungsi untuk menjaring data siswa yang memiliki prestasi sehingga dapat membantu pihak sekolah maupun Kemendikbud dalam pengambilan keputusan untuk memberikan fasilitas pembinaan pendidikan khusus ataupun beasiswa kepada siswa berprestasi.

Terdapat lima tujuan dari penambahan fitur sistem pencarian kepakaran siswa pada Dapodikdas. Pertama melengkapi data siswa sesuai dengan prestasi yang diraih. Kedua, pihak sekolah dapat dengan mudah melacak siswa maupun alumni yang memiliki prestasi, penghargaan, pembinaan dan siswa yang sedang atau mengikuti seleksi baik tingkat kabupaten, provinsi, nasional maupun internasional. Ketiga, menjadi tolak ukur bagi sekolah untuk fokus mengembangkan kegiatan ekstrakurikuler tertentu. Keempat, penyaringan khusus pencarian siswa berbakat dan berprestasi sehinggga dimungkinan bagi pihak Kemendikbud memberikan beasiswa atau pembinaan khusus. Kelima, data prestasi siswa menjadi data yang valid karena data tersebut berada di dalam sistem Dapodikdas yang merupakan aplikasi pemerintah dibidang pendataan siswa yang disahkan oleh undang-undang.

Penelitian tentang dapodikdas pernah dilakukan oleh Azriel Christian Nurcahyo, dan Dema Mathias Lumban Tobing dengan judul Analisis Data Pada Data Pokok Pendidikan Dasar (DAPODIKDAS) SDN 2 Bengkayang Sebagai Bagian Evaluasi Siswa yang dimuat pada SENSITEK 2018 STMIK Pontianak, 12 Juli 2018. Penelitian ini menyimpulkan bahwa langkah 
optimalisasi data dapat dimanfaatkan pihak sekolah maupun operator dalam pencarian meliputi empat kategori yaitu pencarian jumlah siswa, pencarian siswa berjalan kaki, detail orang tua siswa yang berjalan kaki, dan menampilkan jumlah siswa yang menerima KIP [4]. Penelitian rujukan yang kedua adalah tentang perancangan basis data dengan judul Perancangan Basis Data Perputakaan Sekolah dengan Menerapkan Model Data Relasional yang ditulis oleh Gat dari STMIK Pontianak. Penelitian ini dimuat di Citec Journal, Vol. 2, No. 4, Agustus 2015 - Oktober 2015. Pada penelitian ini perancangan basis data perputakaan sekolah dilakukan menggunakan model data relasional dan metode perancangan database DBLC (Data Base Life Cycle) [5]. Rujukan penelitian selanjutnya adalah Membangun Sistem Informasi Kegiatan Kesiswaan Berbasis Web Dengan Pemanfaatan Jquery yang dimuat pada CSRID Journal, Vol.7 No.2 Juni 2015, Hal. 78-89. Penelitian ini ditulis oleh Sri Rahayu, Augury El Rayeb, Daniel Aditya Wibowo dari STMIK RAHARJA yang didalamnya juga membahas tentang perancangan basis data sistem informasi kesiswaan [6].

\section{METODE PENELITIAN}

Metode yang digunakan dalam penelitian ini yaitu pengumpulan data dan perancangan data, sedangkan pada teknik pengumpulan data menggunakan studi pustaka dan observasi. Metode pertama yang dilakukan adalah pengumpulan data yaitu dengan melakukan studi pustaka dari berbagai sumber baik jurnal maupun literatur yang mempunyai keterkaitan dengan bidang yang dibahas.

Selanjutnya melakukan observasi pada sistem terkait yang memiliki kriteria sesuai dengan bidang penelitian dari peneliti. Hal ini bertujuan untuk memberikan gambaran sistem basis data yang akan dibangun. Selanjutnya adalah metode perancangan basis data. Secara umum terbagi menjadi tiga tahapan yaitu conceptual database design, logical database design dan physical database [7].

\subsection{Road Map Penelitian Dapodiknas}

Pada penelitian ini digunakan road map atau peta penentu sebagai tahapan dalam pengembangan sistem dapodikdas sesuai target pencapaian, hasil dan dukungan yang dibutuhkan [8]. Dalam implementasinya digunakan metode diagram tulang ikan atau lebih dikenal fishbone diagram sebagai upaya untuk mempermudah meningkatkan kualitas dalam pencapaian target pengembangan sistem. Metode ini sering disebut dengan diagram Sebab-Akibat. Diagram tulang ikan akan menunjukan sebuah dampak dari sebuah permasalahan dengan berbagai penyebabnya [9]. Merujuk pada gambar diagram tulang ikan digambarkan bahwa terdapat perubahan setiap pengembangan dapodikdas pada ketiga versinya seperti pada Gambar 1. Pada Dapodikdas versi optimalisasi pertama atau dikenal Dapodikdas V2 dilakukan pengembangan dari sisi hak akses yang semula hanya bisa dilakukan oleh operator, pada versi ini guru dapat mengakses dapodikdas untuk menginputkan nilai siswa, sehingga beban operator tidak seberat versi dapodikdas pertama dimana semua data dihandle oleh satu operator. Dengan demikian diharapkan penggunaan dapodikdas menjadi lebih tepat guna. Setelah dilakukan pengembangan dari sisi hak akses, saat ini pengembangan pada versi 3 atau Dapodikdas V3 melakukan pencarian kepakaran yang merujuk kepada prestasi siswa. 
Citec Journal, Vol. 5, No. 4, Agustus 2018 - Oktober 2018

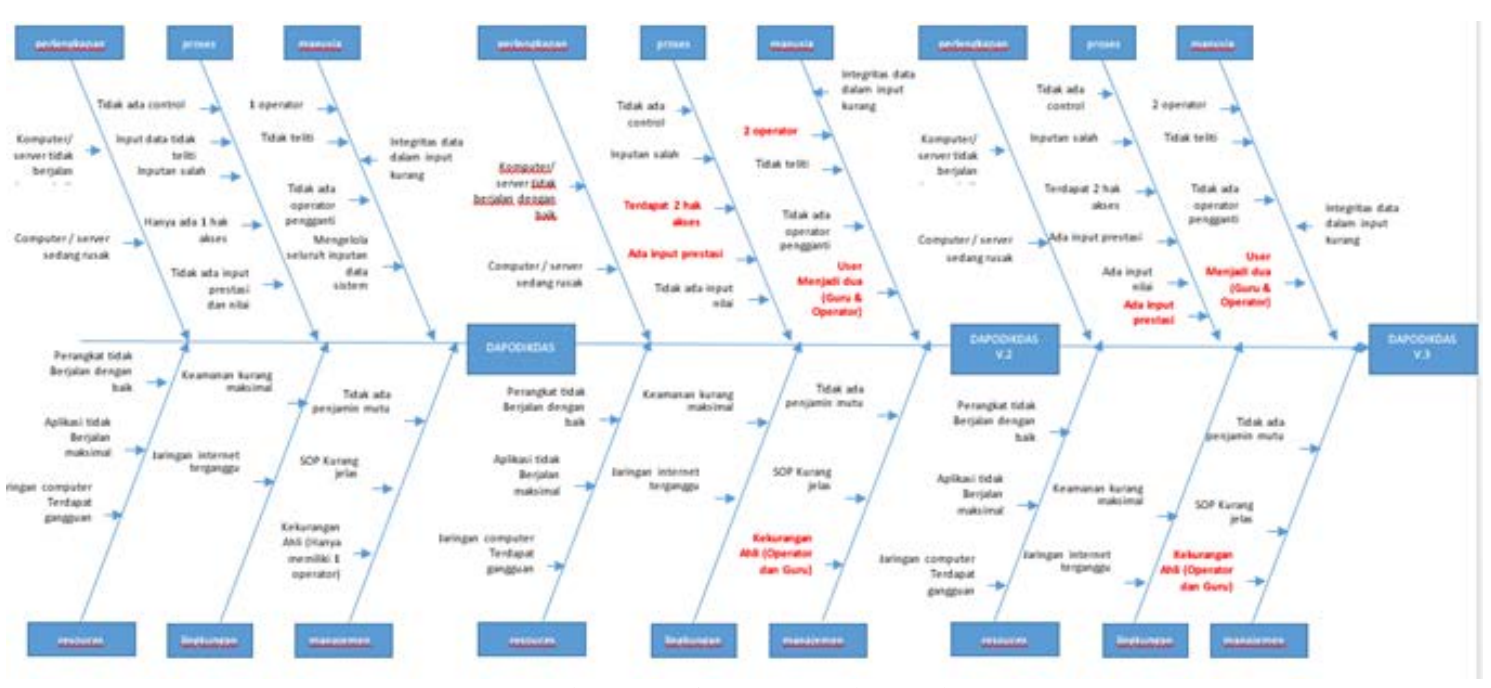

Gambar 1. Diagram Tulang Ikan

Data siswa yang dimiliki sekolah dalam aplikasi Dapodikdas versi pertama dan kedua masih sebatas data pribadi dan nilai akademik siswa belum sampai pada data prestasi tiap siswa, dimana sebenarnya keberadaan data prestasi siswa di sekolah dasar tidak kalah penting. Jika sekolah memiliki data prestasi siswa, maka sekolah akan memiliki acuan data yang valid sebagai dasar pengambilan keputusan, seperti pendanaan ekstrakurikuler yang memiliki prestasi. Dengan berpedoman pada data, diharapakan keputusan yang diambil oleh sekolah akan memiliki prosentase kegagalan yang lebih kecil.

\subsection{Arsitektur Teknologi}

Arsitektur teknologi yang diterapkan di dalam sistem Dapodikdas terpusat pada Pusat Data dan Statistik Pendidikan (PDSP). Data dari sekolah dilakukan sinkronisasi dari operator sekolah ke Direktorat Pendidikan Dasar, kemudian data yang tertampung di Direktorat Pendidikan Dasar diteruskan untuk penyimpanan server Pusat Data dan Statistik Pendidikan (PDSP). Data PDSP inilah yang dipantau oleh operator dapodikdas provinsi maupun kabupaten. Pada kasus tertentu apabila pihak sekolah belum mampu melakukan sinkronisasi data mandiri, dapat dibantu pihak operator kabupaten yang diteruskan ke provinsi untuk disinkronisasi langsung ke Pusat Data dan Statistik Pendidikan seperti pada Gambar 2.

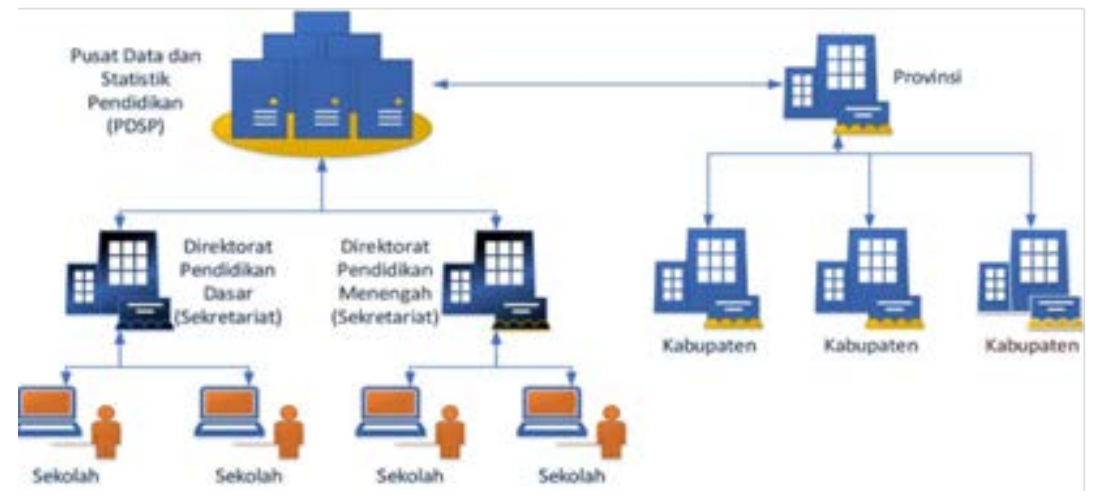

Gambar 2. Arsitektur Teknologi 


\subsection{Perancangan Basis Data}

Sebelum dilakukan implementasi penambahan fitur sistem kepakaran pencarian siswa pada Dapodikdas dilakukan perancangan, dimana perancangan merupakan suatu hal yang sangat penting dalam pembuatan basis data. Permasalahan yang dihadapi ketika dilakukan perancangan adalah bagaimana basis data yang akan dibangun mampu memenuhi kebutuhan saat ini dan masa yang akan datang. Oleh karena itu diperlukan perancangan basis data baik secara fisik maupun secara konseptual. Perancangan konseptual menunjukkan entity dan relasinya berdasarkan proses yang diinginkan oleh organsisasinya. Dalam proses menentukan entity dan relasinya perlu dilakukan analisis data tentang informasi yang ada dalam spesifikasi di masa yang akan datang.

\subsection{Alur Sistem Dapodikdas}

Alur sistem pada penelitian ini dibagi menjadi 2 bagian dimana alur sistem pertama pada Gambar 3 merupakan alur sistem kondisi Dapodikdas saat ini, dan Gambar 4 merupakan alur sistem dari pengembangan Dapodikdas.
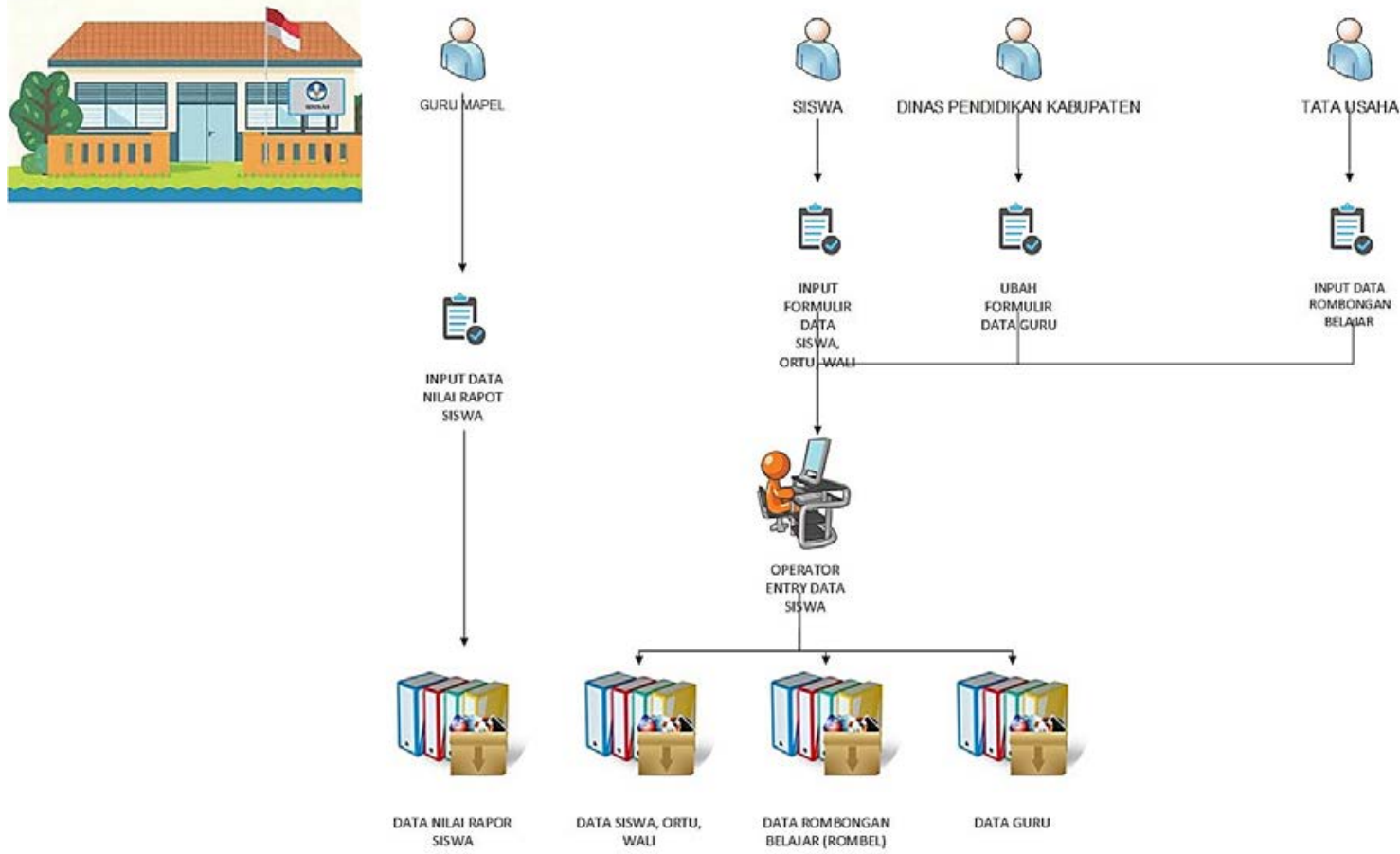

Gambar 3. Alur Sistem yang Sedang Berjalan

Implementasi sistem yang sedang berjalan saat ini, sistem Dapodikdas hanya dapat diakses oleh seorang operator yang telah ditunjuk oleh pihak sekolah sehingga keterlibatan sekolah terhadap sistem ini sangat minim dan resiko kesalahan input yang dilakukan oleh operator sangat besar. Selain itu penginputan terbatas hanya data tenaga pendidik maupun data peserta didik secara umum.

Pada alur sistem Dapodikdas yang sedang dikembangkan terdapat penambahan fitur input prestasi siswa yang dilakukan oleh operator sehingga terdapat data baru yaitu data prestasi. 
Citec Journal, Vol. 5, No. 4, Agustus 2018 - Oktober 2018

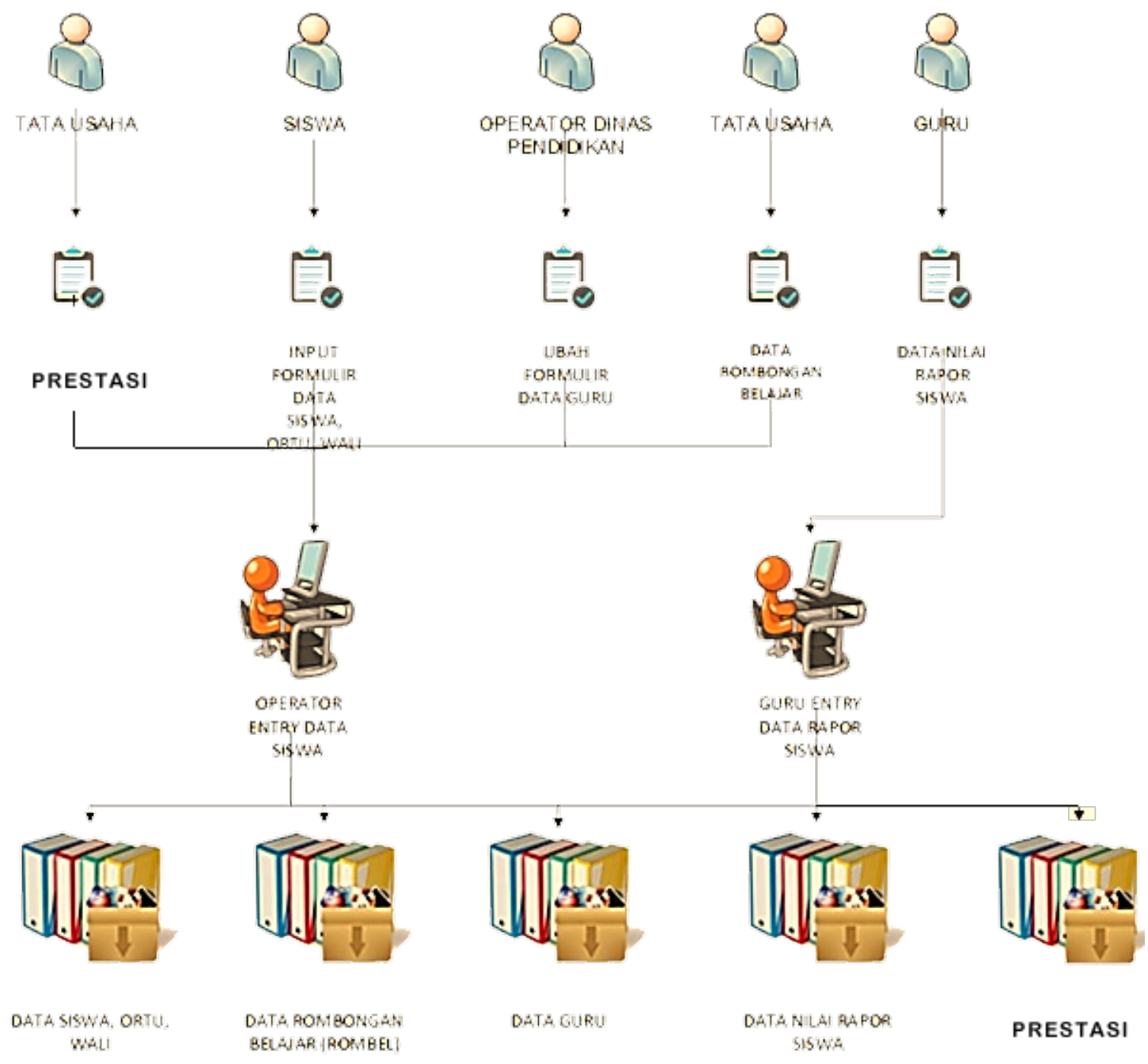

Gambar 4. Alur Sistem yang Dikembangkan

\section{HASIL DAN PEMBAHASAN}

\subsection{Peta Situs}

Pada peta situs Dapodikdas versi optimalisasi yang ditunjukan pada Gambar 5 terdapat empat bagian pembahasan yang terdiri dari tampilan Menu Depan, Data Siswa, Pencarian dan Statistik.

Pada menu Statistik terdapat tiga kategori yaitu penghargaan, pembinaan dan seleksi. Kategori penghargaan dan pembinaan memiliki lima tingkat penghargaan yaitu kecamatan, kabupaten, provinsi, nasional dan internasional, setiap tingkat penghargaan dapat menampilkan data tahun dan data juara. Kategori seleksi memiliki sub kategori yaitu iptek (sains), estetika dan olahraga dimana masing-masing sub kategori tersebut dapat menampilkan sesuai dengan tingkat wilayah seperti kecamatan, kabupaten, provinsi, nasional dan internasional. 


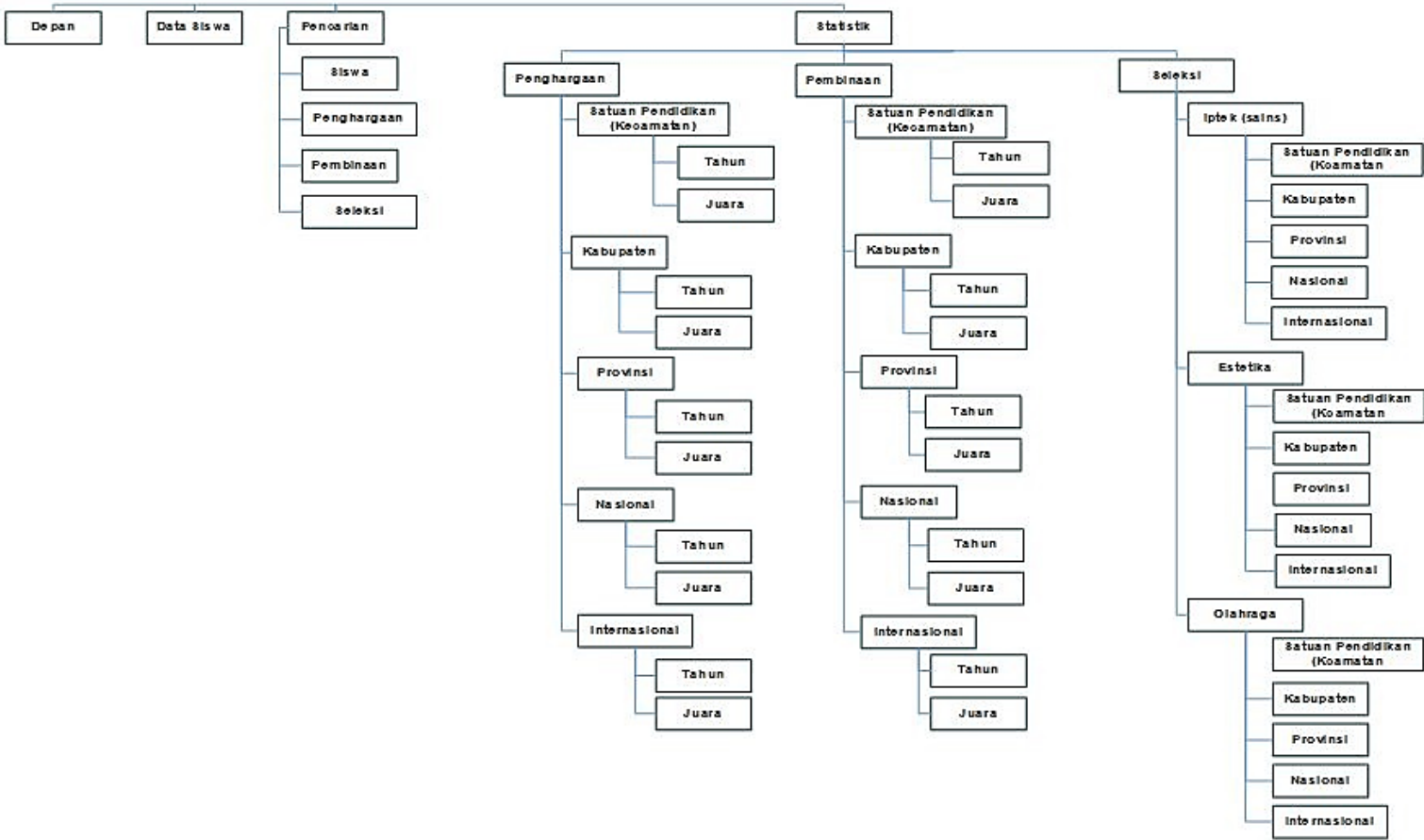

Gambar 5. Peta Situs Dapodikdas

Pada framework utama Dapodikdas versi optimalisasi terdapat tiga menu yaitu Data Siswa, Pencarian dan Statistik, dimana fitur ini sebagai penunjang utama dari keseluruhan fitur sistem pencarian kepakaran.

Pada framework Pencarian, dapat dilakukan penelusuran pada siswa, penghargaan, pembinaan, dan seleksi dengan memasukkan kata kunci pada menu pencarian yang kemudian akan ditampilkan detail sesuai kata kunci yang dimasukkan tersebut. Gambar framework pencarian dapat dilihat pada Gambar 6.

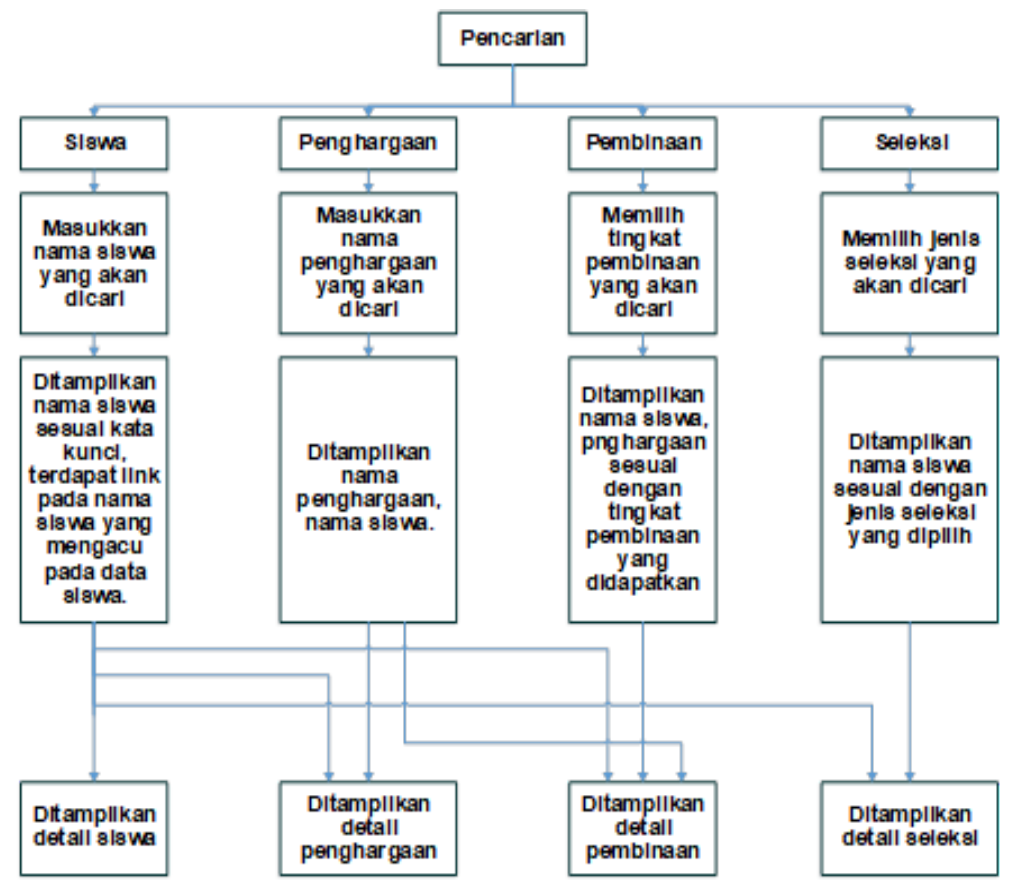

Gambar 6. Framework Pencarian 
Pada framework statistik terdapat tiga sub menu yaitu penghargaan, pembinaan dan seleksi. Bagian sub menu penghargaan dan pembinaan masing-masing memiliki tingkat wilayah seperti kecamatan, kabupaten, provinsi, nasional dan internasional. Setiap tingkat wilayah menampilkan data tahun dan juara seperti pada Gambar 7 tentang Framework Proses Tampil Statistik dan Penghargaan.

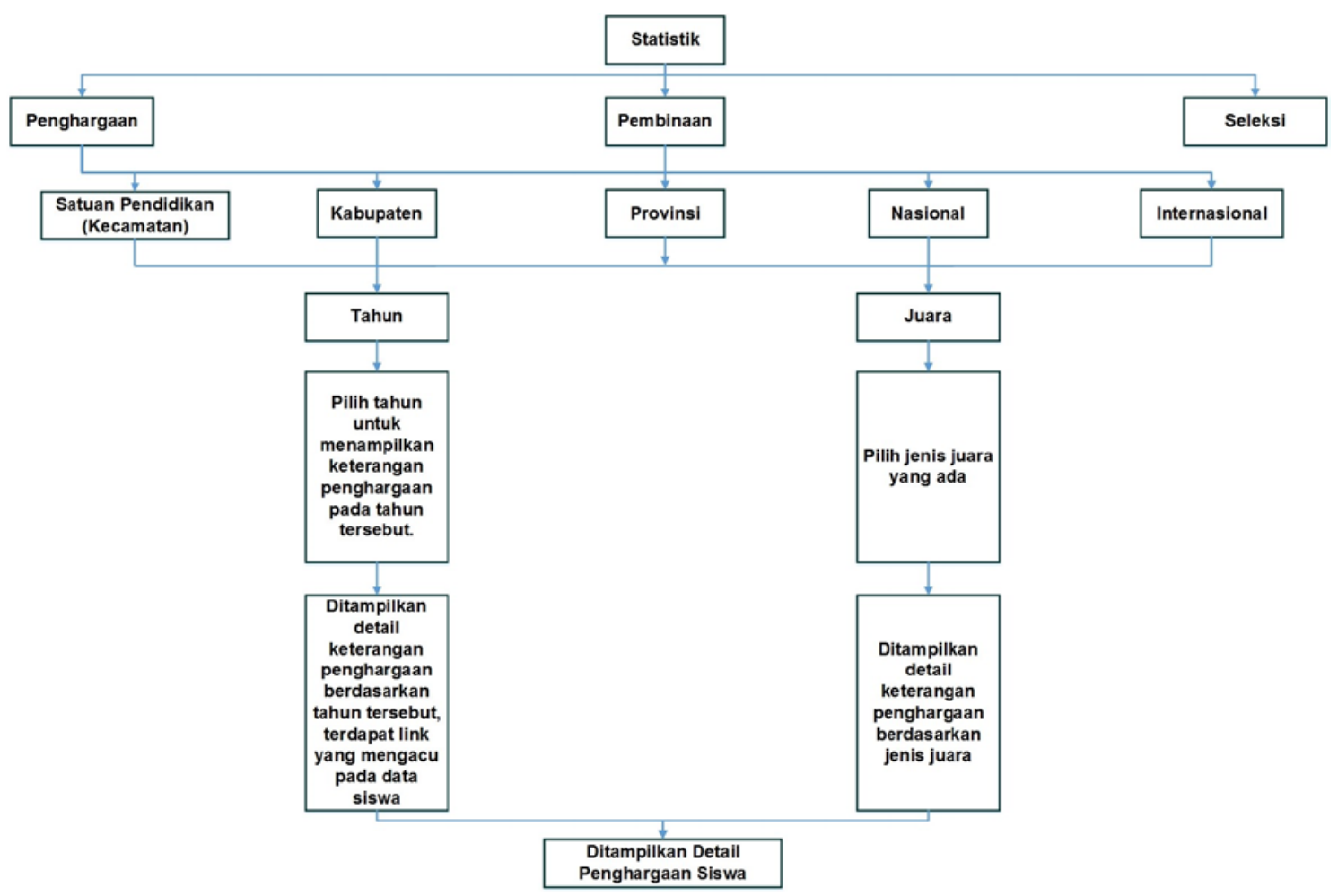

Gambar 7. Framework Proses Tampil Statistik dan Penghargaan

Pada framework statistik ketika user hendak mencari penghargaan atau pembinaan maupun seleksi siswa berprestasi maka ditampilkan hasil berdasarkan tingkat lomba dan berdasarkan tingkat juara serta tahun ketika penghargaan atau pembinaan siswa tersebut didapatkan. Kemudian pada hasil akhir akan ditampilkan detail penghargaan atau detail pembinaan maupun detail seleksi.

\subsection{Relasi Tabel}

Dalam pembuatan database pengembangan sistem Dapodikdas terdapat enam belas tabel yang saling berelasi antara lain sebagai berikut Tabel Guru, Tabel Siswa, Tabel Berita, Tabel Operator, Tabel Mengajar, Tabel Mapel, Tabel Rombel, Tabel Materi, Tabel Nilai, Tabel Kelas Rombel, Tabel Ibu Kandung, Tabel Ayah Kandung, Tabel Wali Siswa, Tabel Penghargaan, Tabel Seleksi dan Tabel Pembinaan. Pada tabel berita terdapat relasi dengan operator yang bertujuan sebagai foreign key yaitu id operator. Pada tabel mengajar terdapat relasi antara tabel guru dan tabel mata pelajaran yang digunakan sebagai pecahan tabel atau tabel baru untuk menghubungkan mata pelajaran dan guru. Pada tabel nilai terdapat relasi antara siswa dan mata pelajaran dengan id siswa dan id mata pelajaran sebagai foreign key. Pada tabel pembinaan, penghargaan dan seleksi terdapat relasi dengan tabel siswa dan id siswa sebagai foreign key. Id siswa diperlukan untuk mengolah data utama yaitu berkaitan dengan prestasi yang diperoleh siswa baik berupa penghargaan, seleksi dan pembinaan yang diterima. Pada tabel siswa berelasi dengan tabel ayah kandung, ibu kandung, wali dan kelas yang berkaitan dengan biodata siswa secara keseluruhan. Pada tabel rombel mempunyai relasi dengan guru dan kelas untuk pembagian tenaga pengajar dalam pembelajaran. 
Pada keenam belas tabel yang terdapat dalam pengembangan sistem Dapodikdas, terdapat tiga tabel utama yang menjadi kunci dari rencangan pengembangan penelitian ini. Ketiga tabel ini adalah fitur utama yang ditambahkan sebagai bagian dari optimalisasi sistem Dapodikdas melalui kepakaran pencarian siswa berprestasi. Ketiga tabel tersebut adalah tabel penghargaan, tabel pembinaan, dan tabel seleksi.

Pertama pada tabel penghargaan, berfungsi mengelola data penghargaan dimana penghargaan id sebagai primary key. Pada tabel penghargaan menyimpan data tingkat penghargaan yang dicapai, tingkat juara, medali dan juga tahun serta keterangan penghargaan seperti pada Gambar 10.

\begin{tabular}{|c|c|c|}
\hline$\#$ & Name & Type \\
\hline 1 & penghargaan_id $P$ & varchar(12) \\
\hline 2 & penghargaan_tingkat & enum 'Kecamatan', 'Kabupaten'. 'Provinsi'. 'Nasion \\
\hline 3 & penghargaan_juara & enum( 1,$2 ;, 3 ;, 7)$ \\
\hline 4 & penghargaan_medali & enum('Emas'. 'Perak'. 'Perunggu'. ') \\
\hline 5 & penghargaan_id_siswa & int(12) \\
\hline 6 & penghargaan_keterangan & text \\
\hline 7 & penghargaan_tahun & year(4) \\
\hline
\end{tabular}

Gambar 10. Tabel Penghargaan

Kedua pada tabel pembinaan, terdiri dari 6 field, dengan data utama yang dapat disimpan berupa data tingkat pembinaan, keterangan pembinaan, tahun pembinaan dan juga tempat pembinaan. Bukti tabel pembinaan dapat dilihat pada Gambar 11.

\begin{tabular}{|lll|}
\hline \# & Name & Type \\
1 & pembinaan_id $\rho$ & varchar(12) \\
2 & pembinaan_tingkat & enum(Kecamatan' 'Kabupaten' 'Provinsi'. Nasion \\
\hline 3 & pembinaan_id_siswa & int(12) \\
\hline 4 & pembinaan_keterangan & text \\
\hline 5 & pembinaan_tahun & year(4) \\
\hline 6 & pembinaan_tempat & varchar(20) \\
\hline
\end{tabular}

Gambar 11. Tabel Pembinaan

Ketiga pada tabel seleksi terdapat data yang dapat diolah dan disimpan antara lain data jenis seleksi, tingkat seleksi, keterangan seleksi dan juga tahun seleksi. Bukti tabel seleksi dapat dilihat pada Gambar 12.

\begin{tabular}{lll}
$\#$ & Name & Type \\
1 & seleksi_id $P$ & varchar(12) \\
\hline 2 & seleksi_jenis & enum('iptek', 'estetika', 'olahraga') \\
3 & seleksi_tingkat & enum('Kecamatan', 'Kabupaten'. 'Provinsi'. 'Nasion \\
4 & seleksi_id_siswa $P$ int(12) \\
\hline 5 & seleksi_keterangan & text \\
\hline 6 & seleksi_tahun & year(4)
\end{tabular}

Gambar 12. Tabel Seleksi

\subsection{Hasil Pengembangan Sistem}

Setelah dilakukan analisa dan perancangan sistem serta implementasi basis data query, maka berikut ini adalah fitur-fitur utama hasil implementasi dari Pengembangan Sistem Dapodikdas menggunakan PHP. Terdapat empat penjelasan meliputi hasil fitur yang 
diimplementasikan antara lain dari tampilan utama aplikasi, kedua fitur pencarian siswa, ketiga detail pencarian siswa, dan keempat detail penghargaan.

Pertama pada tampilan utama, dari pengembangan sistem Dapodikdas terdapat tiga belas menu pada sidebar sistem. Dari ketiga belas menu tersebut, terdapat tiga menu inti yang merupakan bentuk optimalisasi dari kepakaran meliputi menu penghargaan, menu pembinaan, dan menu seleksi seperti yang diperlihatkan pada Gambar 13 tampilan utama. Di samping itu pada menu utama juga ditampilkan berupa statistik data yang dimasukan ke dalam database, antara lain jumlah guru, jumlah penghargaan, dan jumlah siswa.

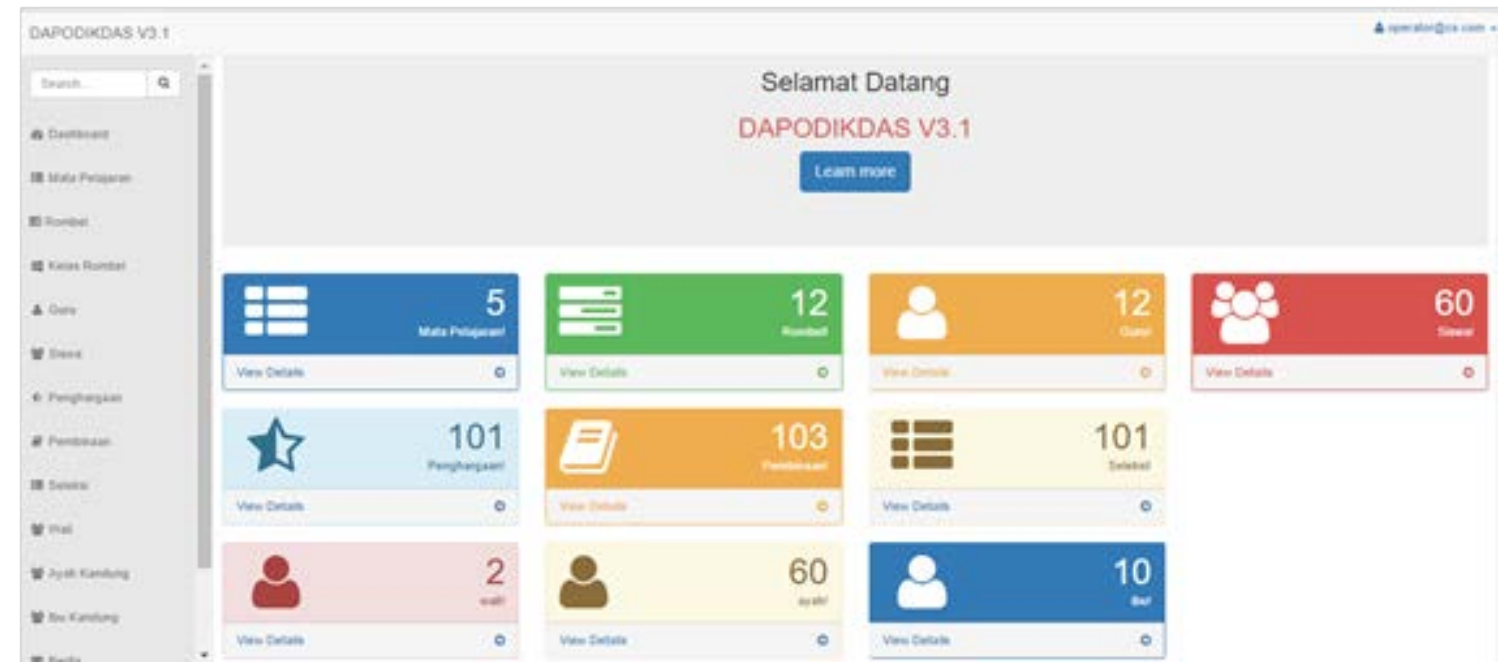

Gambar 13. Tampilan Utama

Kedua pada menu pencarian siswa, digunakan untuk mempermudah pihak sekolah ketika dilakukan penelusuran data siswa. Pihak sekolah hanya perlu melakukan input pada kolom pencarian yang tersedia untuk mencari nama siswa seperti pada Gambar 14. Setelah ditemukan maka akan ditampilkan detail siswa pada menu detail pencarian siswa.

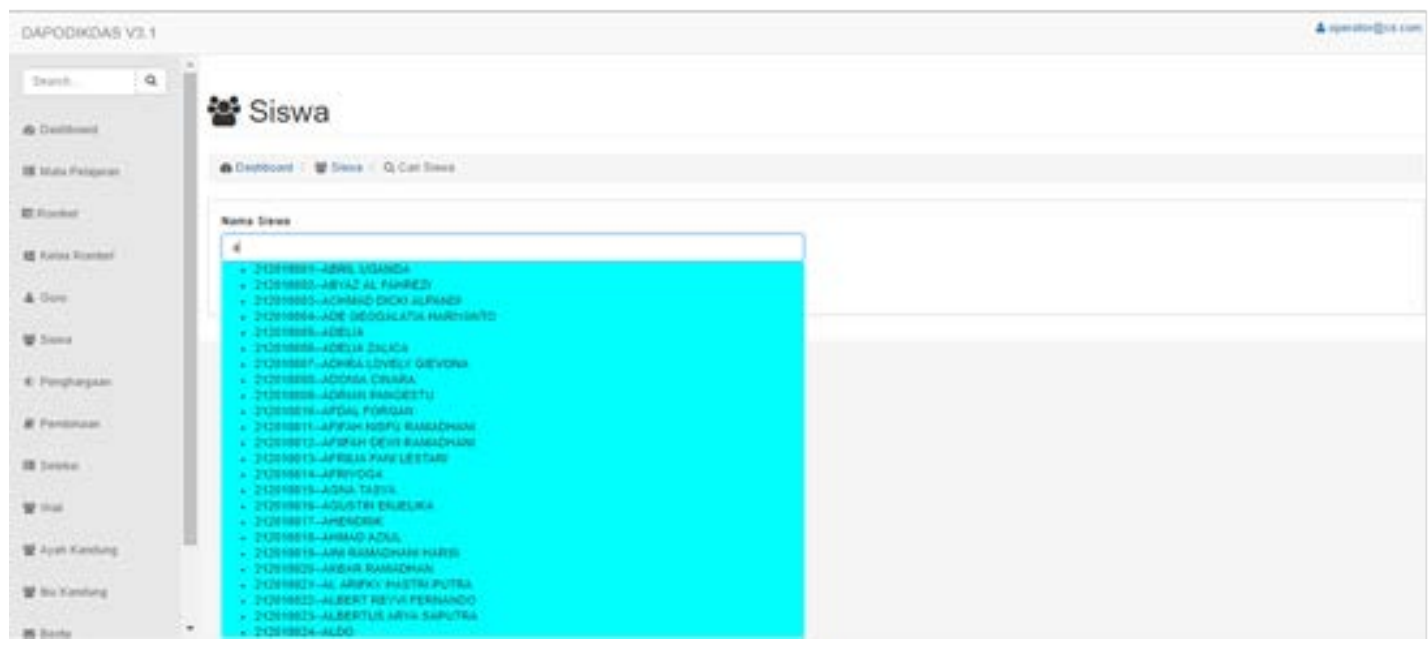

Gambar 14. Tampilan pencarian siswa

Ketiga pada menu detail pencarian siswa akan muncul setelah melakukan akses pada menu pencarian siswa, menu ini menampilkan data seorang siswa yang dipilih baik dari data pribadi siswa hingga data prestasi, seleksi dan penghargaan seperti pada Gambar 15. Data pada penghargaan, seleksi dan pembinaan masih dapat ditelusuri lagi dan akan ditampilkan dalam menu yang terpisah. 


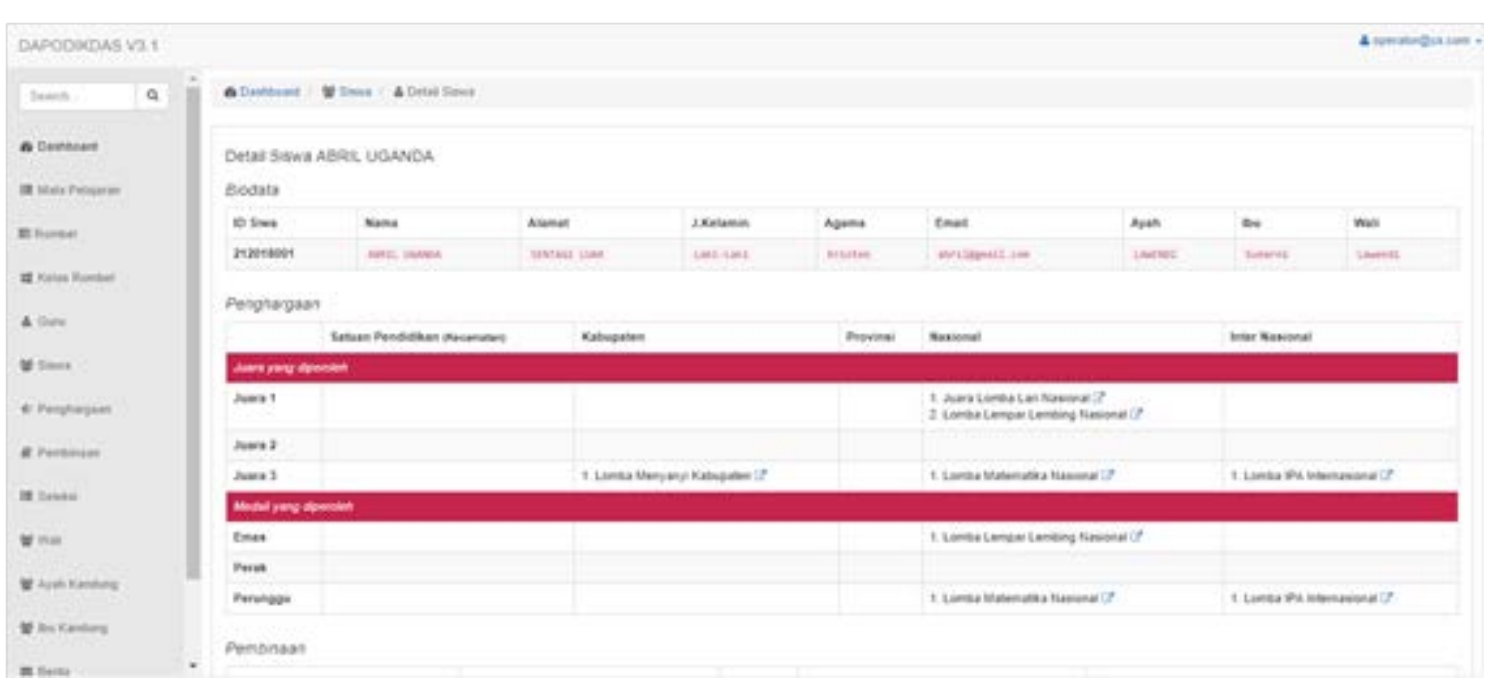

Gambar 15. Tampilan Detail Pencarian Siswa

Keempat pada menu detail penghargaan ditampilkan detail penghargaan yang didapatkan oleh siswa yang dipilih. Menu ini dapat diakses setelah dilakukan penelusuran lebih dalam terhadap penghargaan yang didapatkan oleh siswa. Menu ini menampilkan data yang lebih terperinci mengenai data penghargaan seperti pada Gambar 16.

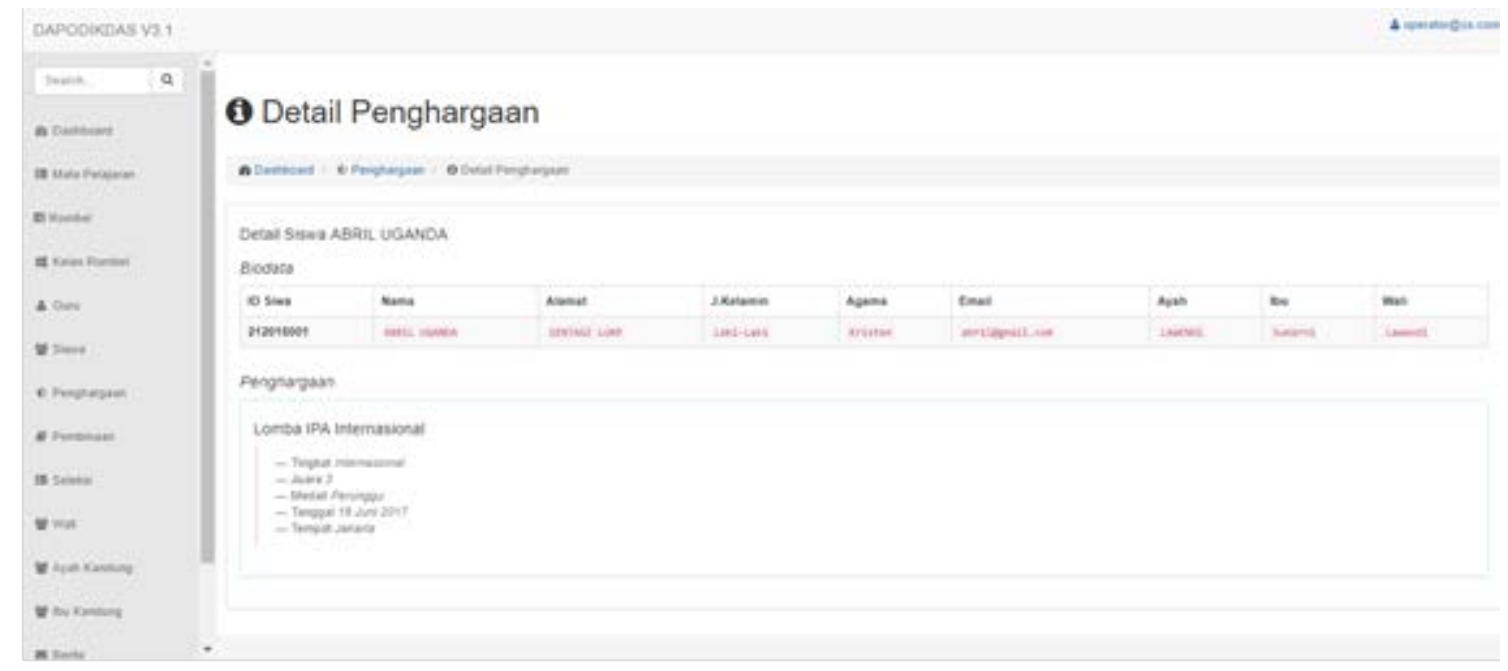

Gambar 16. Tampilan Detail Penghargaan

\subsection{Pengujian Sistem}

Pada penelitian ini dilakukan pengujian sistem menggunakan penggujian database. Pengujian database dilakukan untuk mengetahui kinerja database yang dibuat dengan acuan waktu eksekusi query agar dapat menjadi pertimbangan developer ketika akan dilakukan pengembangan sistem lebih lanjut. Pada sistem Dapodikdas dilakukan pengujian dengan cara mengeksekusi query dengan struktur yang sama pada kedua versi sistem Dapodikdas yakni Dapodikdas real, dan Dapodikdas versi optimalisasi kepakaran. Berikut ini query pengujian yang dilakukan beserta hasil dari pengujian database Sistem Dapodikdas yang berupa pertama query pengujian, dan kedua hasil perbandingan query pengujian.

Pertama dilakukan pengujian query dengan cara menampilkan waktu dari query yang dieksekusi untuk pengujian database adalah sebagai berikut: 
Citec Journal, Vol. 5, No. 4, Agustus 2018 - Oktober 2018

ISSN: 2460-4259

1. Tabel Siswa

Dapodikdas

Hasil Waktu Eksekusi: Showing rows 0 - 24 (504 total, Query took 0.0084 seconds.)

Dari hasil waktu eksekusi didapatkan waktu 0,0084 detik.

Perintah Query sebagai berikut:

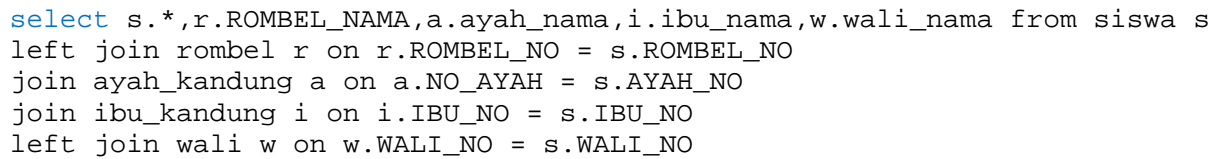

Dapodikdas Versi Optimalisasi Kepakaran Siswa

Hasil Waktu Eksekusi : Showing rows 0 - 24 (60 total, Query took 0.0071 seconds.)

Dari hasil waktu eksekusi didapatkan waktu 0,0071 detik.

Perintah Query sebagai berikut:

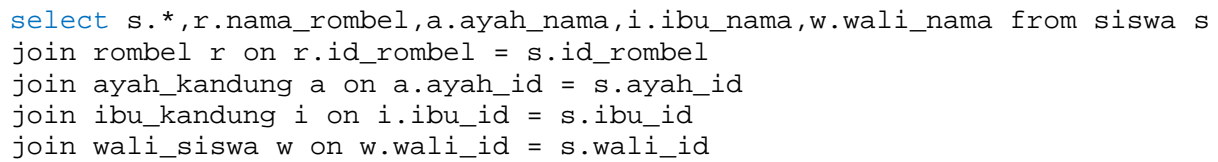

2. Tabel Orang Tua

Dapodikdas

Hasil Waktu Eksekusi: Showing rows 0 - 24 (504 total, Query took 0.0055 seconds.)

Dari hasil waktu eksekusi didapatkan waktu 0,0055 detik.

Perintah Query sebagai berikut :

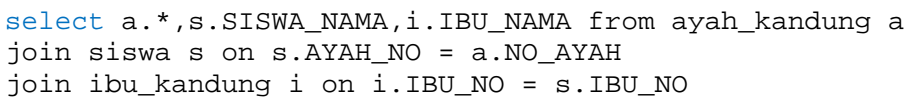

Dapodikdas Versi Optimalisasi Kepakaran Siswa

Hasil Waktu Eksekusi : Showing rows 0 - 24 (60 total, Query took 0.0729 seconds.)

Dari hasil waktu eksekusi didapatkan waktu 0,0729 detik.

Perintah Query sebagai berikut :

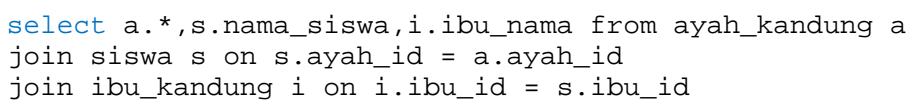

Pada bagian kedua dilakukan perbandingan hasil pengujian database. Setelah dilakukan pengujian dengan query maka di dapatkan hasil perbandingan seperti pada Tabel 1 .

Tabel 1. Hasil Pengujian Database dan Fitur Dapodikdas dengan Dapodikdas versi Optimalisasi

\begin{tabular}{|c|l|c|c|c|c|}
\hline \multirow{2}{*}{ No } & \multicolumn{2}{|c|}{ Pengujian } & \multicolumn{4}{|c|}{ Hasil Uji antara DAPODIKDAS dan } \\
\cline { 3 - 6 } & & DAPODAS Versi Optimalisasi Kepakaran Siswa \\
\hline 1 & $\begin{array}{l}\text { Pencarian Biodata Siswa } \\
\text { Lengkap }\end{array}$ & $\sqrt{ }$ & $\sqrt{ }$ & $\begin{array}{c}0.0084 \\
\text { detik }\end{array}$ & 0.0071 detik \\
\hline 2 & Pencarian Orang Tua & $\sqrt{ }$ & $\begin{array}{c}0.0055 \\
\text { detik }\end{array}$ & 0.0729 detik \\
\hline 3 & Pencarian Kelas & $\sqrt{ }$ & $\sqrt{ }$ & $\mathrm{N}$ & $\mathrm{N}$ \\
\hline 4 & Pencarian Guru & $\sqrt{ }$ & $\sqrt{ }$ & $\mathrm{N}$ & $\mathrm{N}$ \\
\hline 5 & Pencarian Nilai Siswa & & $\sqrt{ }$ & $\mathrm{N}$ & 0.0648 detik \\
\hline 6 & Pencarian Pembinaan Siswa & & $\sqrt{ }$ & $\mathrm{N}$ & 0.0060 detik \\
\hline 7 & Pencarian Seleksi Siswa & & $\sqrt{ }$ & $\mathrm{N}$ & 0.0230 detik \\
\hline 8 & Pencarian Penghargaan Siswa & & $\sqrt{ }$ & $\mathrm{N}$ & 0.0060 detik \\
\hline
\end{tabular}


Dari hasil tersebut dibandingkan pada query pencarian biodata siswa lengkap dan pencarian orang tua dimana Dapodikdas rata-rata lebih cepat 0.00695 detik dibandingkan Dapodikdas versi optimalisasi 0.007195 detik, akan tetapi Dapodikdas belum mampi memenuhi kebutuhan pencarian seperti halnya yang sudah diterapkan pada Dapodikdas versi Optimalisasi Kepakaran Siswa yaitu pencarian pembinaan siswa, seleksi siswa, dan penghargaan siswa.

Pada sebuah design database yang telah diuji, terdapat dua hal yang mempengaruhi kinerja ketika mengeksekusi sebuah query yang dijalankan dijalankan yaitu pertama jumlah tabel yang masuk dalam join query sql dan kedua jumlah data yang terdapat dalam tabel.

\section{KESIMPULAN} berikut.

Dari hasil penelitian yang dilakukan didapatkan tiga kesimpulan antara lain sebagai

1. Penambahan fitur pencarian kepakaran prestasi siswa mampu mengoptimalisasi sistem dapodikdas menjadi lebih lengkap dan akurat dalam menemukan siswa berprestasi baik dalam bidang akademik dan non akademik yang dibuktikan dengan penambahan fitur pencarian pembinaan, seleksi, dan penghargaan.

2. Hasil perbandingan pada query pencarian biodata siswa lengkap dan pencarian orang tua dimana Dapodikdas rata-rata lebih cepat 0.00695 detik dibandingkan Dapodikdas versi optimalisasi 0.007195 detik, akan tetapi belum mampu memenuhi kebutuhan pencarian seperti halnya yang sudah diterapkan pada Dapodikdas versi Optimalisasi Kepakaran Siswa yaitu pencarian pembinaan siswa, seleksi siswa, dan penghargaan siswa.

3. Pada sebuah design database yang telah diuji, terdapat dua hal yang mempengaruhi kinerja ketika mengeksekusi sebuah query yang dijalankan dijalankan yaitu pertama jumlah tabel yang masuk dalam join query sql dan kedua jumlah data yang terdapat dalam tabel.

\section{SARAN}

Dari hasil penelitian yang sudah dilakukan didapatkan saran bahwa optimalisasi dalam fitur penelusuran kepakaran dapat dikembangkan lagi selain pencarian prestasi siswa seperti pada pencarian prestasi guru, orang tua maupun wali murid.

\section{DAFTAR PUSTAKA}

[1] Pemerintah Indonesia Direktur Jenderal Pendidikan Dasar dan Menengah, 2018, Panduan Penggunaan Aplikasi Dapodik Versi 2018.b, Kemendikbud, Jakarta.

[2] Direktur Jenderal Pendidikan Dasar dan Menengah, 2018, Panduan Penggunaan Aplikasi Dapodik Versi 2018.b, Sekretariat Negara, Jakarta

[3] Pemerintah Indonesia Kemendikbud, 2013, Manual Aplikasi DAPODIKDAS 2013. Kemdikbud, Sekretariat Negara, Jakarta.

[4] Nurcahyo, A. C., Tobing, D. M. L., 2018, Analisis Data Pada Data Pokok Pendidikan Dasar (DAPODIKDAS) SDN 2 Bengkayang Sebagai Bagian Evaluasi Siswa, SENSITEK 2018, Pontianak, 12 Juli.

[5] Gat, 2015, Perancangan Basis Data Perputakaan Sekolah dengan Menerapkan Model Data Relasional, Citec Journal, No. 4, Vol. 2, Hal. 304-315. 
Citec Journal, Vol. 5, No. 4, Agustus 2018 - Oktober 2018

[6] Rahayu, S., Rayeb, A, E., Wibowo, D. A., 2015, Membangun Sistem Informasi Kegiatan Kesiswaan Berbasis Web Dengan Pemanfaatan Jquery, CSRID Journal, No. 2, Vol.7, Hal. 78-89

[7] Connoly, T. M., Begg, .C.E., 2010. Database Systems: A Practical Approach to Design, Implementation and Management, Pearson Education, London.

[8] Handayani, W., Sophianingrum, M., Nutriandini, U., 2013, Kajian Roadmap Pengembangan Sistem Inovasi Daerah (Sida) Kota Semarang, Riptek Journal, No. 2, Vol. 7, Hal. 97 - 108

[9] Murnawan, H., Mustofa, 2014, Perencanaan Produktivitas Kerja Dari Hasil Evaluasi Produktivitas Dengan Metode Fishbone di Perusahaan Percetakan Kemasan PT X, Jurnal Teknik Industri HEURISTIC, No. 1, Vol 11, Hal. 27-46 